Arq. Bras. Med. Vet. Zootec., v.67, n.6, p.1735-1742, 2015

\title{
Microbiological and physical-chemical characteristics of fermented milk beverages
}

[Características microbiológicas e físico-químicas de bebidas lácteas fermentadas]

\author{
E.H.P. Andrade ${ }^{1}$, N.M.A. Silva ${ }^{1}$, M.F.S. Resende ${ }^{1}$, M.R. Souza ${ }^{2}$, L.M. Fonseca ${ }^{2}$, \\ M.M.O.P. Cerqueira ${ }^{2}$, C.F.A.M. Penna ${ }^{2}$, M.O. Leite ${ }^{2^{*}}$ \\ ${ }^{1}$ Aluna de pós-graduação - Escola de Veterinária - UFMG - Belo Horizonte, MG \\ ${ }^{2}$ Escola de Veterinária - UFMG - Belo Horizonte, MG
}

\begin{abstract}
This study aimed to evaluate some microbiological and physical-chemical characteristics of fermented milk beverages collected at the main supermarkets in Belo Horizonte (MG). 40 samples of the products corresponding to five distinct brands were collected. They were submitted to the following analyses: Most Probable Number (MPN) of total $\left(30^{\circ} \mathrm{C}\right)$ and thermal tolerant coliforms $\left(45^{\circ} \mathrm{C}\right)$, Salmonella spp., coagulase positive Staphylococcus, molds and yeasts, lactic acid bacteria, $\mathrm{pH}$, titratable acidity and contents of moisture, total solids, protein and fat. The analyses were carried out during the last week of shelf life. The microbiological quality of the samples was good and the counts of lactic bacteria were above the minimum established by the official legislation. Streptococcus and Lactobacillus were isolated and identified from the products and Lactobacillus delbrueckii was molecularly identified in three samples. The mean values for the contents of fat and protein, titratable acidity, $\mathrm{pH}$, moisture and total solids ranged from 1.24 to $1.98 \% ; 1.88$ to $2.22 \%$; 0.54 to $0.66 \% ; 3.91$ to $4.16 ; 81.18$ to $83.25 \%$ and 16.75 to $18.82 \%$, respectively. All samples had protein content in agreement with the official legislation.
\end{abstract}

Keywords: fermented milk beverages, microbiology, physical-chemistry, protein

\section{RESUMO}

O objetivo do presente trabalho foi avaliar as características microbiológicas e físico-químicas de bebidas lácteas fermentadas. Foram coletadas 40 amostras de bebidas lácteas fermentadas pertencentes a cinco marcas distintas, em grandes redes de supermercados de Belo Horizonte. Em cada amostra, foram avaliados os seguintes parâmetros: número mais provável de coliformes totais $\left(30^{\circ} \mathrm{C}\right)$, número mais provável de coliformes termotolerantes $\left(45^{\circ} \mathrm{C}\right)$, pesquisa de Salmonella spp., contagem de Staphylococcus coagulase positiva, contagem de bolores e leveduras, contagem total de bactérias lácticas viáveis, umidade, sólidos totais, teor de proteína, teor de gordura, pH e acidez titulável. As análises foram realizadas na última semana do período de validade. As amostras apresentaram qualidade microbiológica satisfatória, bem como contagens totais de bactérias lácticas viáveis superiores ao mínimo estabelecido pela legislação. Streptococcus e Lactobacillus foram identificados em todas as marcas de bebidas lácteas fermentadas analisadas, e em três delas foi possível identificar a espécie Lactobacillus delbrueckii. Os valores médios encontrados para os teores de gordura, proteína, acidez titulável, $\mathrm{pH}$, umidade e sólidos totais variaram de 1,24 a 1,98\%, 1,88 a 2,22\%, 0,54 a 0,66\%, 3,91 a 4,16, 81,18 a 83,25\% e 16,75 a 18,82\%, respectivamente. Todas as marcas de bebidas lácteas fermentadas apresentaram teor médio de proteína superior ao mínimo preconizado pela legislação.

Palavras-chave: bebidas lácteas fermentadas, microbiologia, físico-química, proteína

Recebido em 17 de outubro de 2014

Aceito em 19 de junho de 2015

*Autor para correspondência (corresponding author)

E-mail: monicaoliveiraleite@gmail.com 


\section{INTRODUCTION}

Milk beverages are resulted from the mixture of milk (in natura, pasteurized, sterilized, UHT, reconstituted, concentrated, powder, whole, partially skimmed or skimmed ) and whey (liquid, concentrated or powder) added or not with other food items, vegetal fat, fermented milk and other milk products, besides lactic starter cultures. Milk basis must represent at least $51 \%(\mathrm{~m} / \mathrm{m})$ of the total ingredients present in the product. A milk beverage is classified as fermented when the mixture milk: whey is added with specific starter microorganisms and/or with fermented milk (Brasil, 2005).

Whey is derived from cheese making or caseinates and their derivatives being separated from the curds contain approximately half of the total solids that were present in the milk used for their processing, ranging from 6.35 to $6.50 \%$. From that total, about 4.85 to $4.90 \%$ is represented by lactose, 0.70 to $0.80 \%$ by proteins (mainly albumins and globulins) and 0.04 to $0.50 \%$ by fat, besides mineral salts (Kosikowski, 1979).

Fermented milk beverages have lower $\mathrm{pH}$ than milk, and metabolites produced by lactic acid bacteria inhibit the growth of undesirable microorganisms. However, some of those microorganisms are able to survive in this type of product when there are contaminations during the processing and storage. Thus, it is very important that fermented milk beverages present microbiological quality according to the official legislation (Brasil, 2005).

Considering the physical-chemical parameters of the fermented milk beverages, only protein content is determined by the official legislation in Brazil. Milk beverages are added with whey and due to that fact may present lower protein content when compared to milk (Brasil, 2005). Considering the high intake of fermented milk beverages by children, their protein content must be investigated in order to attend to the official standards.

According to the Brazilian legislation (Brasil, 2005), the minimum protein content in fermented milk beverages must be $1.7 \%$ in dairy-based components , $1.4 \%$ in beverages mixed with fermented milks and $1.0 \%$ in beverages with addition with non-dairy components.

The aim of the present study was to evaluate some microbiological and physical-chemical characteristics of fermented milk beverages sold by the main supermarkets in Belo Horizonte (MG) in order to investigate compliance with the official legislation.

\section{MATERIAL AND METHODS}

Fermented milk beverages were purchased at the local main supermarkets, considering that they represented the most reliable storage places. Eight samples for each five distinct Federally inspected brands were collected. The microbiological parameters included: Most Probable Number (MPN) of total $\left(30^{\circ} \mathrm{C}\right)$ and thermal tolerant coliforms $\left(45^{\circ} \mathrm{C}\right)$ according to International... (1974), Salmonella spp., coagulase positive Staphylococcus, molds and yeasts according to Brasil (2003), and also counts of lactic acid bacteria (LAB) according to International... (1988).

The colonies of LAB that grew on MRS and M17 agars and showed distinct morphologies were inoculated into $3.0 \mathrm{~mL}$ MRS broth (Difco, Detroit, MI) and incubated at $37^{\circ} \mathrm{C}$ for $72 \mathrm{~h}$ inside the anaerobic chamber or into $3.0 \mathrm{~mL}$ of skim milk powder (Molico, Nestlé), reconstituted at $10 \%$, and were incubated at $37^{\circ} \mathrm{C}$ for $48 \mathrm{~h}$, under aerobiosis. Materials obtained from those colonies were also submitted to catalase test using 30\% hydrogen peroxide and used to prepare smears which were Gram stained.

Gram negative catalase positive bacteria were submitted to molecular identification using the amplified ribossomal DNA restriction analysis (ARDRA). The amplified region was 16S-23S according to Tisala-Timisjarvi and Alatossava (1997), Tannock et al. (1999) and Moreira et al. (2005). The following endonucleases were used: SphI, NcoI, NheI, SspI, SfuI, DraI, VspI, AvrII, EcoRI, HincII, HindIII e EcoRV (Promega Corporation, Madison, Wisconsin, EUA).

Some physical-chemical parameters were also evaluated in duplicate. $\mathrm{pH}$ was determined using a digital pHmeter (Hanna Instruments, São Paulo, SP, Brasil). Fat content was determined using the butyrometer. Moisture content was 
determined by oven drying (Biopar Equipamentos Eletro-eletrônicos Ltda, Porto Alegre, RS, Brasil) . Protein content was determined by Micro-Kjedahl, using the device Tecnal (TE012, Piracicaba, SP, Brasil).

Descriptive statistics was applied to microbiological results. Simple random sample was used to analyze physical-chemical results. Comparisons of means were performed by Student-Newman-Keuls test, at 5\% (Sampaio, 2002) using the SAS program, version 8.0 (SAS Institute Inc, Cary, Carolina do Norte, EUA).

\section{RESULTS AND DISCUSSION}

Only one sample $(2.5 \%)$ of fermented milk beverage was contaminated by total coliforms with a MPN of $0.3 / \mathrm{mL}$. MPN $/ \mathrm{mL}$ of thermal tolerant coliforms was lower than 0.3 in all samples. Those results point out the appropriate sanitary hygienic quality during the processing and storage of the analyzed fermented milk beverages, with microbiological quality in compliance with the official Brazilian legislation (Brasil, 2005). Rodrigues and Santos (2007) and Tebaldi et al. (2007) also reported similar results when evaluating the same product.

Results of Salmonella spp., coagulase-positive Staphylococcus and counts of molds and yeasts are presented in Table 1. The Brazilian Agency for Sanitary Surveillance (ANVISA) recommends that Salmonella spp. must be absent in the analyzed products (Brasil, 2001). This fact is postulated since this bacterium is a pathogen and may cause toxinfection in humans.

Staphylococcus spp. show a high potential to contaminate foods and produce toxins which may cause food poisoning and represent a risk to public health. Several food legislations require the analysis of coagulase negative Staphylococcus in foods, since that enzyme is correlated with toxins production. However, Bartels et al. (2009) demonstrated staphylococcal toxins production by coagulase- negative Staphylococcus . Similar to what was verified in the present study, Pinto et al. (2009) did not isolate coagulase-positive Staphylococcus in three brands of fermented milk beverages.

Table 1. Results of microbiological analyses of fermented milk beverages collected at the main supermarkets in Belo Horizonte (MG)

\begin{tabular}{cc}
\hline Analyses & Results \\
\hline Salmonella spp. & Absence in $100 \%$ \\
coagulase-positive & $<10 \mathrm{CFU} / \mathrm{mL}$ in $100 \%$ \\
Staphylococcus & \\
Molds and yeasts & 1 sample $-2.4 \times 10^{4} \mathrm{CFU} / \mathrm{mL}$ \\
& 39 samples $-<10 \mathrm{CFU} / \mathrm{mL}$
\end{tabular}

*In compliance with RDC $\mathrm{n}^{\circ} 12$ from the Brazilian Agency for Sanitary Surveillance (Brasil, 2001)

Among the analyzed samples in the present study, only one $(2.5 \%)$ presented count of molds and yeasts of $2.4 \times 10^{4} \mathrm{CFU} / \mathrm{mL}$. In the other samples, the counts were below $10 \mathrm{CFU} / \mathrm{mL}$. These results point out that there was not contamination by those microorganisms originated from environment, packaging or ingredients in almost all analyzed samples. Besides, the samples were added with potassium sorbate, which is used to avoid mold and yeast growth in foods. Tebaldi et al. (2007) did not detect the presence of mold and yeast in fermented milk beverages, similarly to the results of the present study.

Table 2 shows the results related to lactic acid bacteria counts in fermented milk beverages. In two out of five brands of the analyzed fermented milk beverages, counts of LAB were above $3.0 \mathrm{x}$ $10^{8} \mathrm{CFU} / \mathrm{mL}$. For the other brands, only in one repetition of each one, $\mathrm{LAB}$ counts were lower than $3.0 \times 10^{8} \mathrm{CFU} / \mathrm{mL}$, being $2.66 \times 10^{8}$ and $1.79 \times 10^{8} \mathrm{CFU} / \mathrm{mL}$. These results point out an excellent microbiological quality, being superior to that established by the Brazilian legislation (Brasil, 2005), which recommends a minimum count of LAB of $10^{6} \mathrm{CFU} / \mathrm{mL}$ in fermented milk beverages throughout its shelf life. 
Table 2. Number of repetitions of fermented milk beverages which presented LAB counts above and below $3.0 \times 10^{8} \mathrm{CFU} / \mathrm{mL}$ in each brand

\begin{tabular}{cccc} 
Brand & $\begin{array}{c}\text { Repetitions with counts } \\
>3.0 \times 10^{8} \mathrm{CFU} / \mathrm{mL}\end{array}$ & $\begin{array}{c}\text { Repetitions with counts } \\
<3.0 \times 10^{8} \mathrm{CFU} / \mathrm{mL}\end{array}$ & Total \\
\hline 1 & 7 & 1 & 8 \\
2 & 7 & 1 & 8 \\
3 & 8 & 0 & 8 \\
4 & 6 & 2 & 8 \\
5 & 8 & 0 & 8 \\
\hline
\end{tabular}

From the 36 samples of bacteria submitted to molecular identification, 13 were isolated on M17 agar and 23 on MRS agar. From those that grew on M17 agar, $12(92.3 \%)$ had one band after PCR 16S-23S, suggesting Streptococcus spp. The other sample from M17 agar was not amplified. From the 23 samples that grew on MRS agar, 4 (17.4\%) had three bands suggesting
Lactobacillus spp. Other 16 samples isolated from the same medium had three bands amplified, suggesting Streptococcus spp. Figure 1 shows the distribution of LAB isolated from fermented milk beverages and Figure 2 shows the PCR 16S-23S amplification using agarose gel.

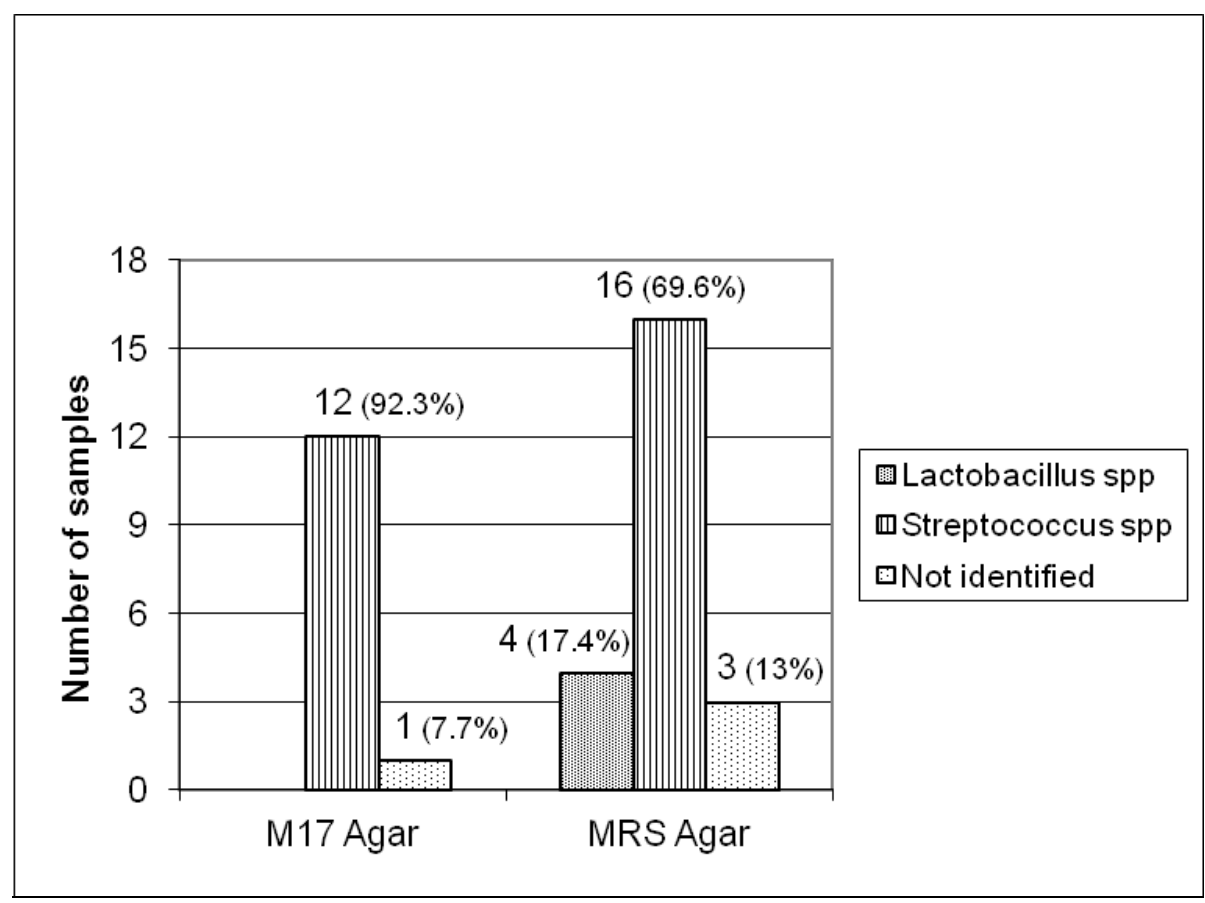

Figure 1. Distribution of LAB isolated from fermented milk beverages on M17 and MRS agars after PCR $16 \mathrm{~S}-23 \mathrm{~S}$.

The PCR ARDRA 16S-23S of the three bacteria that presented three bands after PCR revealed that all were Lactobacillus delbrueckii. In two out of five brands of fermented milk beverages, microorganisms showing three bands after PCR $16 \mathrm{~S}-23 \mathrm{~S}$ were not found. However, Gram staining indicated the presence of Gram positive rods and the catalase test was negative. The presence of catalase negative, Gram positive coccus in some samples was also observed. 


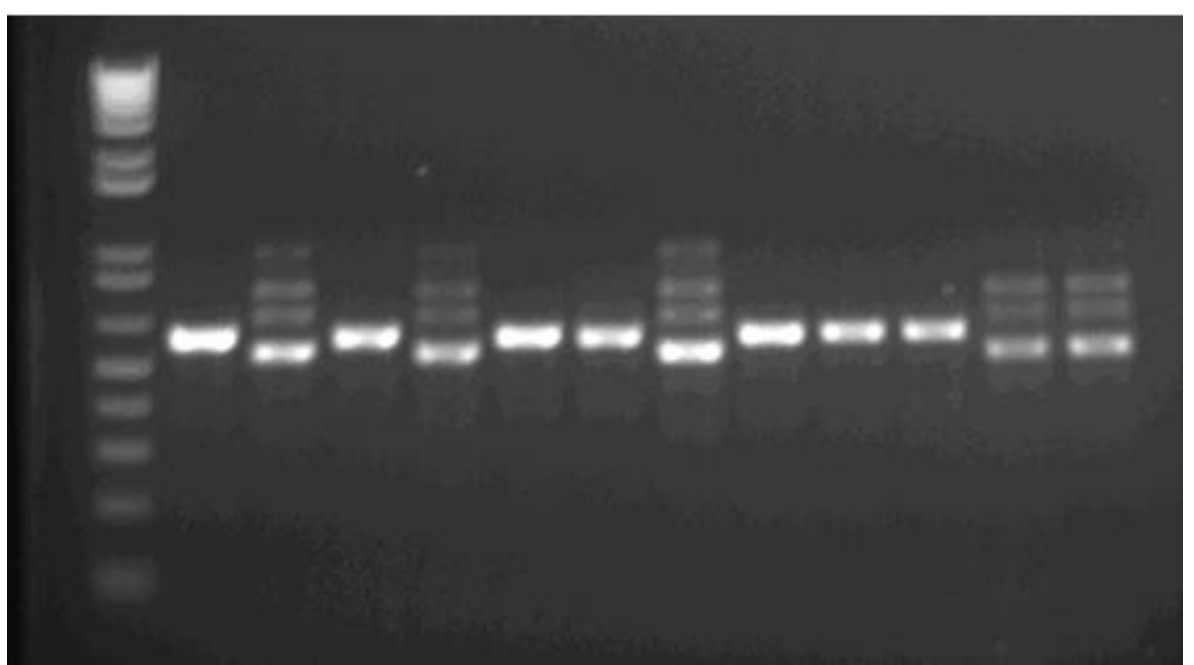

Figure 2. Photo of agarose gel of the PCR ARDRA 16S-23S rDNA of lactic acid bacteria isolated from fermented milk beverages collected at supermarkets from Belo Horizonte (MG). Rows from left to right: $1 \mathrm{~kb}$ molecular weight marker; 2, 4, 6, 7, 9, 10 and 11. Samples that had one amplified band were suggestive of Streptococcus spp.; 3, 5, 8, 12 and 13. Samples that had three amplified bands Lactobacillus spp.

Those results confirm that the fermented milk beverages were produced using yogurt mesophilic starter cultures, which are composed by Streptococcus thermophilus ssp. salivarius and Lactobacillus delbrueckii ssp. bulgaricus. The Brazilian legislation does not establish one specific starter culture for fermented milk beverage processing, it only determines the minimum count of those bacteria throughout the shelf-life (Brasil, 2005).

Table 3 shows the mean fat content $(\mathrm{g} / 100 \mathrm{~g})$ in the fermented milk beverages. Only one brand presented lower values $(\mathrm{P}<0.05)$ of fat content compared to the others.

Table 3. Mean results, standard deviations and coefficients of variation $(\mathrm{CV})$ of fat content $(\mathrm{g} / 100 \mathrm{~g})$ in fermented milk beverages collected in Belo Horizonte (MG)

\begin{tabular}{ccc}
\hline Brand & $\begin{array}{c}\text { Mean Fat }(\mathrm{g} / 100 \mathrm{~g}) \pm \\
\text { standard deviation }\end{array}$ & $\mathrm{CV}(\%)$ \\
\hline 4 & $1.24 \mathrm{a} \pm 0.12$ & 9.68 \\
2 & $1.71 \mathrm{~b} \pm 0.18$ & 10.53 \\
1 & $1.76 \mathrm{~b} \pm 0.45$ & 25.57 \\
5 & $1.80 \mathrm{~b} \pm 0.12$ & 6.66 \\
3 & $1.98 \mathrm{~b} \pm 0.17$ & 8.59 \\
\hline
\end{tabular}

Distinct letters after means indicate different results by the Student-Newman-Keuls test $(\mathrm{P}<0.05)$
The Brazilian legislation does not establish a standard for inspection of fat content in fermented milk beverages (Brasil, 2005). However, several consumers are seeking foods with lower fat content.

Almeida et al. (2001) produced fermented milk beverages with the addition of 30,40 and $50 \%$ of whey. Their mean values of fat content were $1.92,1.76$, and $1.59 \mathrm{~g} / 100 \mathrm{~g}$, respectively. These results are similar to those found in the present study. Cunha et al. (2008) produced a fermented milk beverage with the addition of $30 \%$ of whey and verified a fat content of $1.91 \mathrm{~g} / 100 \mathrm{~g}$, also similar to the means found in the present study.

Table 4 shows the mean of protein content in the fermented milk beverages. According to the Brazilian legislation (Brasil, 2005) the minimum content of this parameter must be $1.4 \mathrm{~g} / 100 \mathrm{~g}$ in milk beverages added with fermented milks and $1.0 \mathrm{~g} / 100 \mathrm{~g}$ for milk beverages with additions or milk beverages added with food items.

All the samples presented protein content higher than the minimum established by the Brazilian legislation (Brasil, 2005). This fact has a great importance since those foods are widely consumed by children that require a higher daily intake of protein in their diet. 
Table 4. Mean results, standard deviations and coefficients of variation $(\mathrm{CV})$ of protein content $(\mathrm{g} / 100 \mathrm{~g})$ in fermented milk beverages collected in Belo Horizonte (MG)

\begin{tabular}{ccc}
\hline Brand & $\begin{array}{c}\text { Mean protein }(\mathrm{g} / 100 \mathrm{~g}) \pm \\
\text { standard deviation }\end{array}$ & $\mathrm{CV}(\%)$ \\
\hline 4 & $2.22 \mathrm{a} \pm 0.22$ & 9.90 \\
3 & $2.17 \mathrm{a} \pm 0.10$ & 4.60 \\
5 & $1.94 \mathrm{~b} \pm 0.15$ & 7.73 \\
2 & $1.91 \mathrm{~b} \pm 0.05$ & 2.61 \\
1 & $1.88 \mathrm{~b} \pm 0.31$ & 16.49 \\
\hline
\end{tabular}

Distinct letters after means indicate different results by the Student-Newman-Keuls test $(\mathrm{P}<0.05)$

Almeida et al. (2001) reported mean protein contents of 2.14. 1.97 and $1.94(\mathrm{~g} / 100 \mathrm{~g})$ in fermented milk beverages produced with additions of 30,40 and $50 \%$ of whey, respectively. Those values are similar to those verified in the present study. Chinelate et al. (2005) evaluated the protein content in fermented milk beverages from six brands purchased at the market in Fortaleza, Ceará. Mean values obtained for each brand were 1.09, 1.15, 1.18, 1.22. 1.52 and $2.02(\mathrm{~g} / 100 \mathrm{~g})$, which were lower than those described in the present study. Oliveira (2006) also reported similar values of protein content - from 1.65 to $2.08 \mathrm{~g} / 100 \mathrm{~g}$ - in fermented milk beverages fortified with iron, presenting different concentrations of whey, after storage for seven days at $4^{\circ} \mathrm{C}$. Cunha et al. (2008) reported protein content of $2.23 \mathrm{~g} / 100 \mathrm{~g}$ in fermented milk beverages produced with the addition of $30 \%$ whey and fermented by termophilic starter composed by Streptococcus salivarius ssp. thermophilus, Lactobacillus acidophilus and Bifidobacterium. That result was close to the mean values observed in brands 3 and 4 analyzed in the present study.

Table 5 presents mean values of titratable acidity and $\mathrm{pH}$ of the different brands of fermented milk beverages. There are not official standards for inspection of titratable acidity and $\mathrm{pH}$ of fermented milk beverages in Brazil. However, assuming the standards established for fermented milk (Brasil, 2007), which establishes a minimum of $0.60 \%$ of titratable acidity, means of brands 2, 3, 4 and 5 for that parameter would be in compliance with the legislation. Since the samples were analyzed at the end of the shelflife, higher values would be expected for those parameters. This explanation would also be appropriate to justify the low $\mathrm{pH}$ values recorded.

Table 5. Mean results, standard deviations and coefficients of variation (CV) of titratable acidity (g of lactic acid/100g) and $\mathrm{pH}$ in fermented milk beverages collected in Belo Horizonte (MG)

\begin{tabular}{ccccc}
\hline Brand & $\begin{array}{c}\text { Titratable acidity }(\%) \\
\text { Mean } \pm \text { standard } \\
\text { deviation }\end{array}$ & $\mathrm{CV}(\%)$ & $\begin{array}{c}\mathrm{pH} \\
\text { Mean and standard } \\
\text { deviation }\end{array}$ & $\mathrm{CV}(\%)$ \\
\hline 5 & $0.66 \mathrm{a} \pm 0.047$ & 7.12 & $3.94 \mathrm{a} \pm 0.11$ & 2.80 \\
4 & $0.65 \mathrm{ab} \pm 0.093$ & 14.31 & $4.16 \mathrm{~b} \pm 0.10$ & 2.40 \\
2 & $0.65 \mathrm{ab} \pm 0.026$ & 4.00 & $3.91 \mathrm{a} \pm 0.06$ & 1.53 \\
3 & $0.61 \mathrm{ab} \pm 0.082$ & 13.44 & $4.11 \mathrm{~b} \pm 0.12$ & 2.92 \\
1 & $0.54 \mathrm{~b} \pm 0.140$ & 25.93 & $4.05 \mathrm{~b} \pm 0.12$ & 2.96 \\
\hline
\end{tabular}

Distinct letters after means indicate different results by Student-Newman-Keuls test $(\mathrm{P}<0.05)$.

Almeida et al. (2001) found titratable acidity results similar to those from the present study when evaluated fermented milk beverages produced with yogurt starter culture and added with 30,40 and $50 \%$ of whey and stored for 28 days.

The $\mathrm{pH}$ differences in the fermented milks may be related to the type and quantity of starter culture used for their manufacture, besides the activity of the bacteria, $\mathrm{pH}$ established to stop the fermentation process, quantity of whey, different ingredients and time of storage (Thamer and
Penna, 2006). Oliveira (2006) studied ironfortified fermented milk beverages prepared with three distinct concentrations of whey and stored for seven days at $4^{\circ} \mathrm{C}$. The mean value of $\mathrm{pH}$ was 4.13 for the products prepared with 10 and $30 \%$ of whey and 4.20 for the product prepared with $50 \%$ of whey.

Table 6 shows the mean values of moisture and total solids in the fermented milk beverages. The Brazilian legislation (Brasil, 2005) does not establish criteria for the inspection of those parameters. 
Table 6. Mean results, standard deviations and coefficients of variation (CV) of moisture and total solids in fermented milk beverages collected in Belo Horizonte (MG)

\begin{tabular}{ccccc}
\hline Brand & $\begin{array}{c}\text { Moisture (\%) mean } \pm \\
\text { standard deviation }\end{array}$ & CV $(\%)$ & $\begin{array}{c}\text { Total solids mean and } \\
\text { standard deviation }\end{array}$ & CV $(\%)$ \\
\hline 2 & $83.25 \mathrm{a} \pm 0.84$ & 1.00 & $16.75 \mathrm{a} \pm 0.84$ & 5.01 \\
5 & $82.93 \mathrm{a} \pm 0.91$ & 1.10 & $17.07 \mathrm{a} \pm 0.91$ & 5.33 \\
3 & $82.15 \mathrm{ab} \pm 1.50$ & 1.83 & $17.85 \mathrm{ab} \pm 1.50$ & 8.40 \\
1 & $81.25 \mathrm{~b} \pm 1.07$ & 1.32 & $18.75 \mathrm{~b} \pm 1.07$ & 5.71 \\
4 & $81.18 \mathrm{~b} \pm 0.73$ & 0.90 & $18.82 \mathrm{~b} \pm 0.73$ & 3.88 \\
\hline
\end{tabular}

Distinct letters after means indicate different results by the Student-Newman-Keuls test $(\mathrm{P}<0.05)$

The manufacturers of fermented milk beverages have been adding some additives to the products, such as starch, stabilizers and strainers. Although the legislation aforementioned did not establish the maximum concentration of these chemicals in the products, it would be very important to determine the standards for the inspection of moisture and total solids in fermented milk beverages.

Chinelate et al. (2005) found mean values of $13.89,19.26,17.85,16.77,18.60$ and $15.77 \%$ for total solids content in six brands of fermented milk beverages, which were similar to the ones reported in the present study. Cunha et al. (2008) described mean values of $18.08 \%$ for total solids content and $81.91 \%$ for moisture content in fermented milk beverages produced with $30 \%$ of whey. Starter culture was composed by Streptococcus salivarius ssp. thermophilus, Lactobacillus acidophilus and Bifidobacterium spp. Those values are similar to the ones verified in the present study.

\section{CONCLUSION}

Retailed Fermented milk beverages collected at supermarkets in Belo Horizonte (MG) presented appropriate microbiological quality in compliance with the Brazilian legislation. Protein content of the analyzed products was above the official standard. The necessity for the establishment of other physical-chemical parameters besides protein content for fermented milk beverages by the Brazilian inspection authorities should be stressed.

\section{ACKOWLEDGEMENTS}

To the Conselho Nacional de Desenvolvimento da Pesquisa (CNPq) and Fundação de Amparo à Pesquisa (FAPEMIG) for financial support.

\section{REFERENCES}

ALMEIDA, K.E.; BONASSI, I.A.; ROÇA, R.O. Características físicas e químicas de bebidas lácteas fermentadas e preparadas com soro de queijo Minas Frescal. Cienc. Tecnol. Alim., v.21, p.187-192, 2001.

BARTELS, A.S.; ANDRADE, A.D.; NEUMANN, E. et al. Identificação de portadores de Staphylococcus enterotoxigênicos e avaliação de susceptibilidade a antimicrobianos. Arq. Bras. Med. Vet. Zootec., v.61, p.1450-1453, 2009.

BRASIL. Mistério da Saúde. Resolução RDC $\mathrm{n}^{\mathrm{o}} 12$ de 02 de janeiro de 2001. Aprova o Regulamento Técnico sobre padrões microbiológicos para alimentos. Diário Oficial da União, Brasília, DF, 10 de janeiro de 2001. Disponível em: <http://elegis.anvisa.gov.br/leisref/public/form.php?lang=pt $>$. Acessado em: 11 set. 2008.

BRASIL. Ministério da Agricultura, Pecuária e Abastecimento. Instrução Normativa $n^{\circ} 62$ de 26 de agosto de 2003. Oficializa os métodos analíticos oficiais para análises microbiológicas para controle de produtos de origem animal e água. Diário Oficial da União, Brasília, DF, 18 de setembro de 2003. Seção 1, p.14. Disponível em: $<\mathrm{http}$ //extranet.agricultura.gov.br/sislegisconsulta/con sultarLegislacao.do?operacao=visualizar\&id $=2851>$. Acessado em: 20 ago. 2008.

BRASIL. Ministério da Agricultura, Pecuária e do Abastecimento. Instrução Normativa $\mathrm{n}^{\circ} 16$, de 23 de agosto de 2005. Aprova o Regulamento técnico de Identidade e Qualidade de Bebidas Lácteas. Diário Oficial da União, Brasília, DF, 24 de agosto de 2005. Seção 1, p.7. Disponível em: $<$ http://extranet.agricultura.gov.br/sislegisconsulta/con sultarLegislacao.do?operacao=visualizar\&id=12792 >. Acessado em: 19 ago. 2008. 
BRASIL. Ministério da Agricultra, Pecuária e do Abastecimento. Instrução Normativa $n^{\circ} 46$, de 23 de outubro de 2007. Adota o Regulamento técnico de Identidade e Qualidade de Leites Fermentados. Diário Oficial da União, Brasília, DF, 24 de outubro de 2007. Seção 1, p.5. Disponível em: <http://extranet.agricultura.gov.br/sislegisconsulta/con sultarLegislacao. do operacao=visualizar\&id $=18164$ >. Acessado em 31 mar. 2009.

CHINELATE, G.C.B.; TELLES, F.J.S.; VIEIRA, J.M.M. et al. Sólidos totais, viscosidade e teor de proteínas de bebidas lácteas fermentadas, produzidas no estado do Ceará. In: CONGRESSO NACIONAL DE LATICÍNIOS, 22., 2005, Juiz de Fora. Anais... Juiz de Fora: CT/ILCT - EPAMIG, 2005. p.147-149. (Resumo expandido).

CUNHA, T.M.; CASTRO, F.P.; BARRETO, P.L.M. et al. Avaliação físico-química, microbiológica e reológica de bebida láctea e leite fermentado adicionados de probióticos. Semina: Cienc. Agrar., v.29, p.103-116, 2008.

KOSIKOWSKI, F.V. Whey utilization and whey products. J. Dairy Sci., v.62, p.1149-1160, 1979.

MILK and milk products: enumeration of coliforms colony count technique and most probable number technique at $30^{\circ} \mathrm{C} . I D F$ Standard, 73A, 1974.

MOREIRA, J.L.S.; MOTA, R.M.; HORTA, M.F. et al. Identification to the species level of Lactobacillus isolated in probiotic prospecting studies of human, animal or food origin by $16 \mathrm{~S}-23 \mathrm{~S}$ rRNA restriction profiling. BMC Microbiol., v.5, p.1-9, 2005.

OLIVEIRA, V.M. Formulação de bebida láctea fermentada com diferentes concentrações de soro de queijo, enriquecida com ferro: caracterização físicoquímica, análises bacteriológicas e sensoriais. 2006. 78f. Dissertação (Mestrado em Medicina Veterinária) - Faculdade de Veterinária, Universidade Federal Fluminense, Niterói, RJ.
PINTO, A.M.; DIAS, L.F.; OLIVEIRA, A.A. et al. Avaliação microbiológica de bebida láctea fermentada comercializadas na cidade de Viçosa-MG. In: CONGRESSO BRASILEIRO DE HIGIENISTAS DE ALIMENTOS. 13., 2009, Florianópolis. Anais... Florianópolis: Colégio Brasileiro de Médicos Veterinários Higienistas de Alimentos, 2009. CD ROM. (Resumo).

RODRIGUES, M.A.M.; SANTOS, K.A. Qualidade microbiológica de iogurtes e bebidas lácteas fermentadas, comercializadas em Uberlândia, Minas Gerais. Hig. Alim., v.21, p.39-40, 2007.

SAMPAIO, I.B.M. Estatística aplicada à experimentação animal. 2.ed. Belo Horizonte: Fundação de Ensino e Pesquisa em Medicina Veterinária e Zootecnia, 2002. 265 p.

STATISTICAL Analisys Systems. Version 8.0. Cary: SAS Institute Inc., 1999.

TANNOCK, G.W.; TISSALA-TIMISJARVI, A.; RODTONG, S. et al. Identification of Lactobacillus isolates from the gastro-intestinal tract, silage and yoghurt by the 16S-23S rRNA gene intergenic spacer region sequence comparisons. Appl. Environm. Microbiol., v.65, p.4264-4267, 1999.

TEBALDI, V.M.R.; RESENDE， J.G.O.S.; RAMALHO, G.C.A. et al. Avaliação microbiológica de bebidas lácteas fermentadas adquiridas no comércio varejista do sul de Minas Gerais. Cienc. Agrotec., v.31, p.1085-1088, 2007

THAMER, K.G.; PENNA, A.L.B. Caracterização de bebidas lácteas funcionais fermentadas por probióticos e acrescidas de prebiótico. Ciênc. Tecnol. Alim., v.26, p.589-595, 2006.

TISSALA-TIMISJARVI, A.; ALATOSSAVA, T. Development of oligonucleotide primers from the 16S-23S rRNA intergenic sequences for identifying different dairy and probiotic lactic acid bacteria by PCR. Int. J. Food Microbiol., v.35, p.49-56, 1997.

YOGURT: enumeration of characteristic microorganisms colony count technique at $37^{\circ} \mathrm{C}$. IDF Standard, 117A, 1988 